45. A Contribution to the Anatomy of a Hammerhead Shark (Zygcena malleus Shaw). By J. H. Lloyd, M.Sc. (Birm.), F.Z.S., and Edith M. Sheppard, B.Sc. (Wales), F.Z.S., Zoological Department, University College, Cardiff.

[Received April 20, 1922 : Read November 21, 1922.]

\title{
(Text-figures $1-7$.
}

The specimen on which this paper is based was given to us by Professor W. N. Parker, of University College, Cardiff, to whom our best thanks are due for his generosity. The specimen was sent to him some years ago by the late J. J. Neale, Esq., a local trawler owner, but unfortunately the fishermen had eviscerated it immediately after it was caught.

Text-figures $1 \& 1 a$.

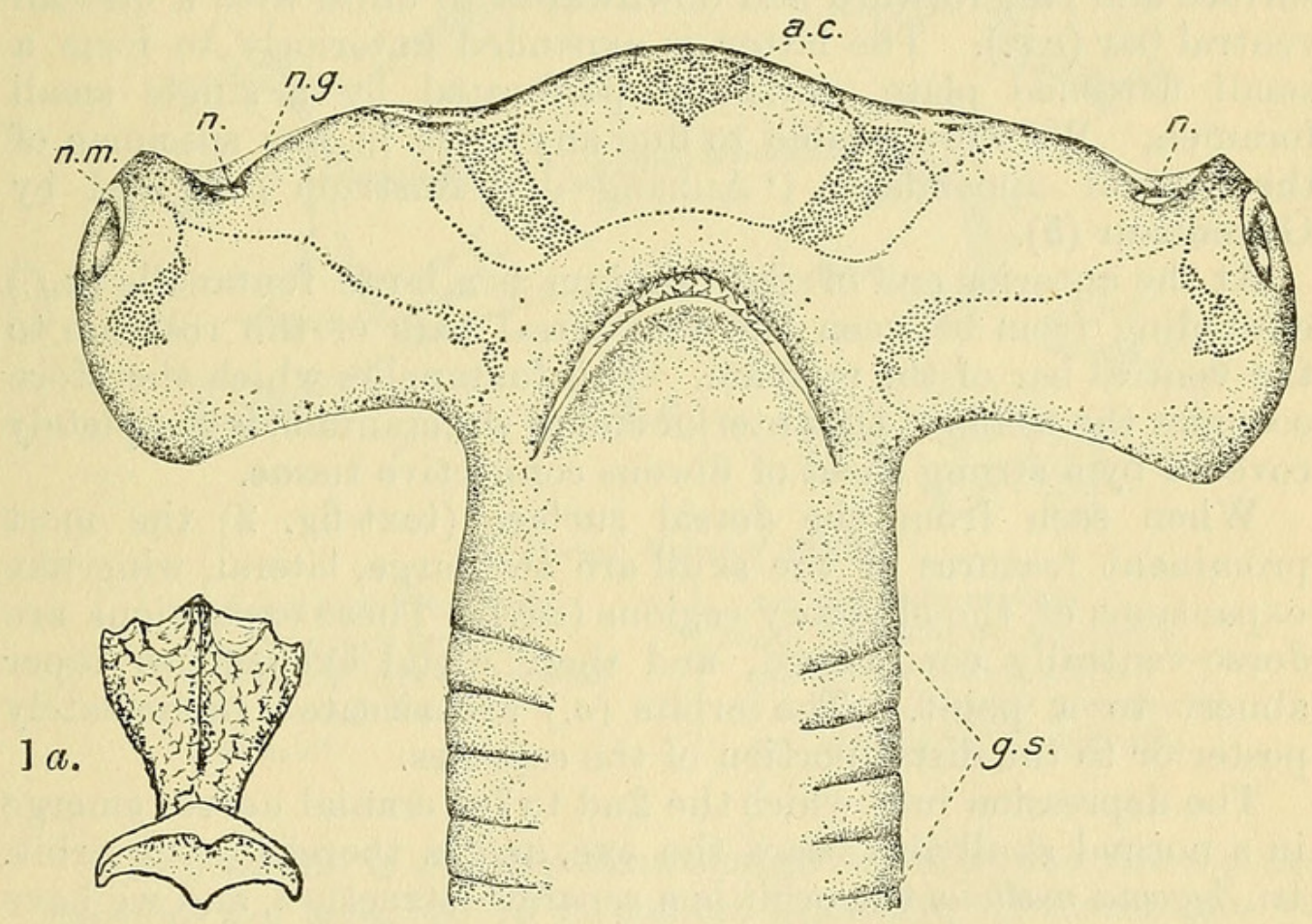

Head in Ventral View.

a.c. ampullary canals. g.s. gill slits. n. nostril. $n . g$. nasal groove.

n.m. nictitating membrane.

1 a. Dermal Denticle.

In this short paper we intend to include notes on the structure of the skull, brain, cranial nerves, and membranous labyrinth. Owing to the long immersion in spirit to which the specimen had been subjected the preparation of the skeleton proved to be a 
matter of some difficulty, as the connective tissue had hardened to an extraordinary extent and the cartilage had become exceedingly brittle. We hope later to publish an account of the structure of the visceral arches, limb-girdles, vertebral column, and fins.

A description of this fish appears to be desirable as, with the exception of the external characters, we have not been able to find any consecutive account of its anatomy.

Both Garman (4) and Day (3) have given a species definition and figured the entire animal, the former including it in the genus Cestracion under the name of Cestracion zygana Linn. Gegenbaur (5) gives two figures of the head and briefly mentions the species in his text, but our observations do not agree with his in all respects. The macroscopic structure of the brain has been briefly described and figured by Busch (2) and Miklucho-Maclay (12).

\section{SKULL.}

The cranium bears at its anterior end a stout rostrum which consists of three bars. Two of these (d.r.) arise from the dorsal surface and run forward and downwards to unite with a median ventral bar $(v . r$.$) . The latter is expanded anteriorly to form a$ small flattened plate, which is perforated by a single small foramen. We were unable to find any trace in our specimen of the rostral appendages ('Anhang der Rostrum') figured by Gegenbaur (5).

At the anterior end of the cranium is a large fontanelle (a.f.) extending from between the two dorsal bars of the rostrum to the ventral bar of the rostrum. This fontanelle, which therefore occupies the whole of the anterior end of the cranium, is completely covered by a strong sheet of fibrous connective tissue.

When seen from the dorsal surface (text-fig. 2) the most prominent features of the skull are the large, lateral, wing-like expansions of the olfactory regions (o.c.). These expansions are dorso-ventrally compressed, and their distal extremities taper almost to a point. The orbits (o.) are situated immediately posterior to the distal portion of the capsules.

The depression into which the 2 nd to 7 th cranial nerves emerge in a normal skull also bears the eye, and is therefore the orbit. In Zygana malleus the orbit is a separate structure, and we have therefore decided to call the depression into which the above mentioned cranial nerves emerge the pre-auditory depression (p.a.d.). This has resulted in a few other changes in the nomenclature of related parts, but it appears preferable to us to do this rather than to retain terms which give incorrect impressions of the relationships of the regions to one another.

The orbit is composed of a post-olfaciory process (p.o.) which runs backwards and outwards from the olfactory capsule to form the anterior three-quarters of the circumference of the orbit on the dorsal surface. The orbit is completed dorsally by a bar of 
cartilage, the auditory process (a.p.), which arises from the anterodorsal corner of the auditory capsule. The auditory process broadens out distally, and the broad distal portion forms the posterior fourth of the orbit. The process throughout its length acts as a support to the posterior border of the hammer. The relations of this bar and the shape of the orbit are incorrectly figured by Gegenbaur (5).

The olfactory capsules are dorso-ventrally flattened and project laterally from the front of the cranium. They do not come into apposition with one another in the median longitudinal line. Each cartilaginous capsule is completely closed except for the small nostril. which is situated antero-ventrally and a short distance from the distal end.

Text-figure 2.

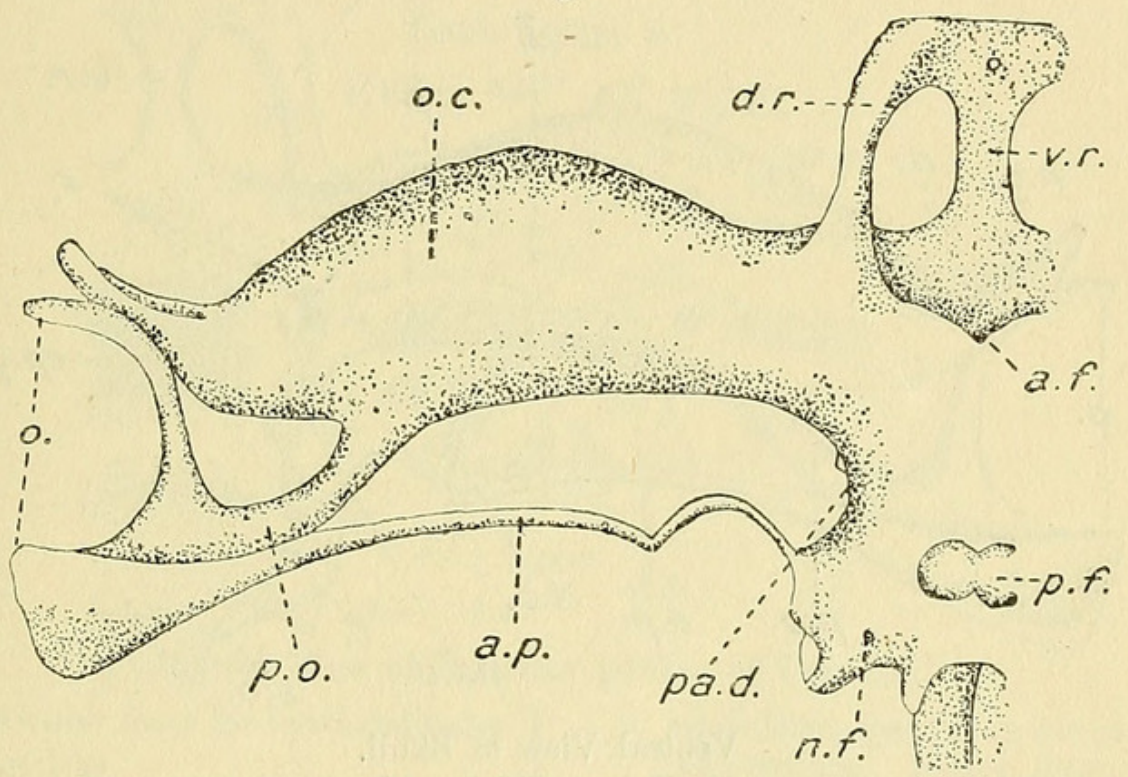

Dorsal View of Skull.

\begin{abstract}
a.f. anterior fontanelle.
a.p. auditory process.

d.r. dorsal bars of rostrum.

$n . f$. nerve foramen.

$o$. orbit.
\end{abstract}

o.c. olfactory capsule. p.a.d. pre-auditory depression. p.f. posterior fontanelle. p.o. post-olfactory process. $v . r$. ventral bar of rostrum.

The cranium is slightly dome-shaped dorsally, and the auditory capsules are attached to it postero-laterally. Between the two auditory capsules, and on the dorsal surface of the cranium is a shallow median depression, the posterior fontanelle $(p . f$.$) . This$ fontanelle contains four apertures, two on each side, which will be referred to later in the description of the membranous labyrinth.

Each auditory capsule exhibits on its dorsal surface a supraauditory process (sa.p.) which extends upwards from the socket, which is found on the side of the capsule, for the articulation of the hyomandibular. About half an inch mesial to each supraauditory process is a small foramen for the passage of a nerve. 
The ventral view of the skull shows that a groove, about one inch in length, runs from the distal end of the olfactory capsule to the nostril. The end of the capsule also serves as a further support to the anterior of the orbit. Gegenbaur (5) has incorrectly figured the extent of the cavity of the olfactory capsule and the position of the nostril.

A very slender bar (s.c.) of fibrous tissue, which is perforated by a fine canal, runs from the auditory process to the olfactory capsule, and then runs along the posterior edge of the capsule. The structure of this bar suggests that it is a sensory canal. It is figured as far as it could be traced in our specimen, but we do not believe that it is complete. It has been figured, for about a

\section{Text-figure 3.}

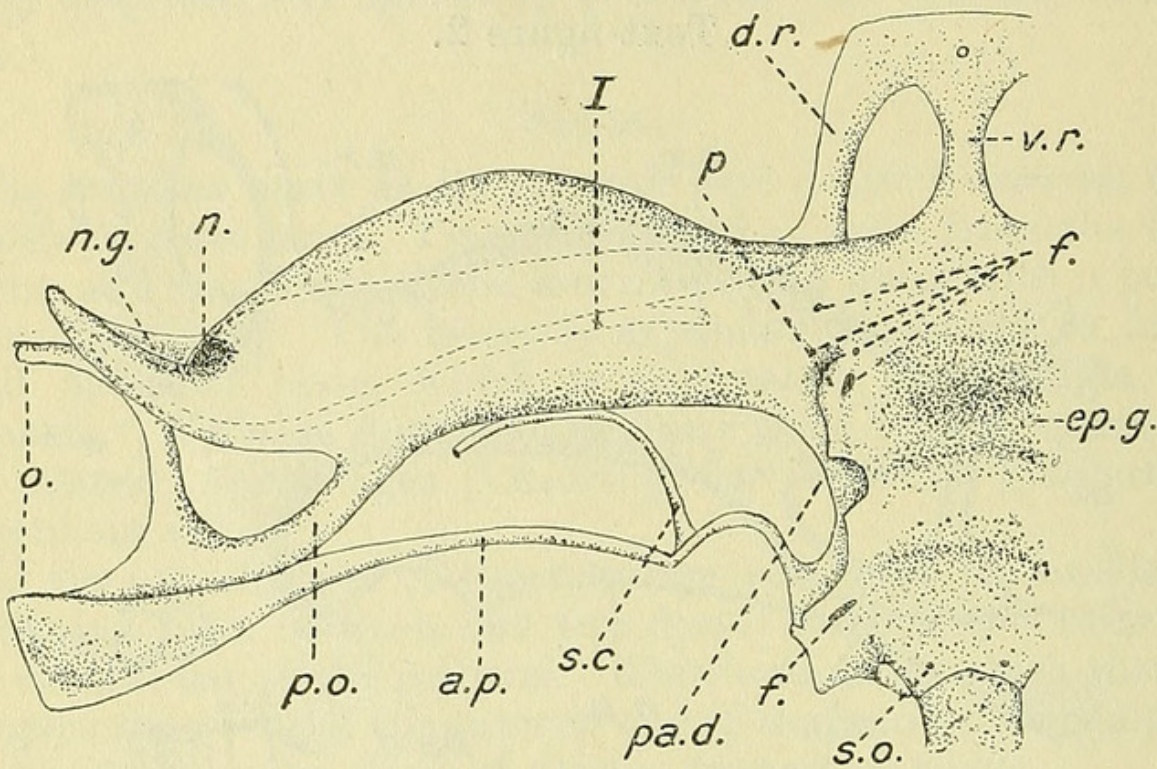

Ventral View of Skull.

ep.y. ethmo-palatine groove.

$f$. foramina.

n. nostril.

n.g. nasal groove.

s.c. sensory canal.

s.o. 1st spino-occipital foramen. $p$. process on cranium for articulation of ethmopalatine process.

I. olfactory nerve. The dotted area anterior to the nerve indicates the extent of the olfactory sac.

third of the length shown in our drawing, by Gegenbaur (5), and he has lettered it $(x)$, but does not explain it in any way.

The ventral side of the cranium (text-fig. 3 ) is marked by a deep ethmopalatine groove (ep.g.) into which fits the narrowed middle portion of the upper jaw. On each side of this narrowed portion of the jaw is an ethmopalatine process. Each of these fits against a corresponding process $(p$. ) on the cranium, one being situated immediately anterior to each of the two outer edges of the ethmopalatine groove. The processes on the cranium are perforated on the mesial side by a single large foramen, which opens dorsally into the pre-auditory depression In addition in this regior there are four smaller foramina on each side. 
Another pair of large foramina, one on each side, is seen perforating the inferior pre-auditory ridge (i.p.r.), which runs anteriorly from the auditory capsule.

Two small apertures (s.o.) ventral to the foramen magnum serve for the passage of the first spino-occipital nerve.

The posterior view of the skull shows the apertures for the ninth and tenth cranial nerves in the normal position; the fairly large foramen of the vagus nerve $(x)$ at the sides of the occipital processes, and the small foramen for the glossopharyngeal nerve (IX) at the postero-lateral corner of the auditory capsule.

The posterior portion of the skull seen in lateral view (textfig. 4) shows a number of foramina. The most posterior of these is that of the vagus nerve $(x)$, and slightly anterior to this is the foramen of the glossopharyngeal nerve (IX).

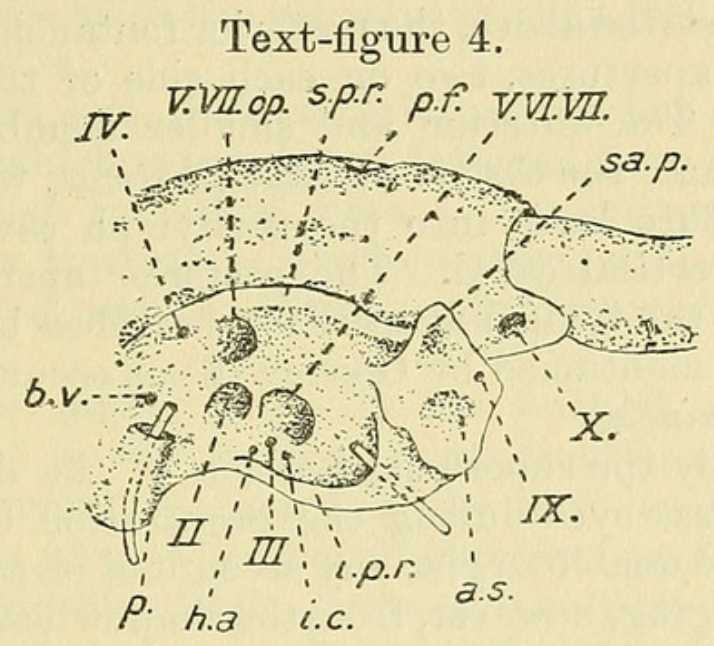

Lateral View of Posterior portion of Cranium.

a.s. articular facet for hyomandibular cartilage.

b.v. passage for blood-vessel.

h.a. passage for hyoidean artery.

i.c. interorbital canal.

i.p.r. inferior pre-auditory ridge. $p$. articulating process on ventral side of cranium. Seeker inserted to show large foramen.

sa.p. supra-auditory process.

s.p.r. superior pre-auditory ridge.

The posterior seeker marks the foramen perforating the inferior pre-auditory ridge.

II-X. Cranial nerves.

The pre-auditory depression exhibits the following apertures:the largest, which is situated near the posterior of the depression, is the foramen of the fifth, sixth, and seventh cranial nerves ( $\mathrm{V}, \mathrm{VI}, \mathrm{VII}$ ), excepting the ophthalmic branches of the fifth and seventh nerves. Ventral to this are three small apertures, the anterior of which serves for the passage of the hyoidean artery (h.a.). The posterior of the three is the interorbital canal (i.c.). The third aperture, which is situated between and slightly dorsal to the others, is the foramen of the third cranial nerve (III).

The large optic foramen (II) is situated immediately anterior to the foramen of the chief branches of the fifth and seventh and 
the sixth nerves, and the single foramen of the ophthalmic branches of the fifth and seventh nerves (V \& VII, op .) is immediately dorsal to it.

In front of the ophthalmic foramen is a small aperture which serves for the exit of the pathetic nerve (IV), and ventral and slightly anterior to this is a small opening for the passage of a blood-vessel (b.v.).

The pre-auditory depression is bounded on its dorsal and ventral edges by well-marked superior and inferior pre-auditary ridges. The inferior ridge (i.p.r.) is the better developed and runs forward from the auditory capsule to the olfactory capsule. The superior ridge (s.p.r.) becomes less marked anteriorly and disappears before reaching the olfactory capsule.

\section{Membranous Labyrinth.}

As has been stated above, the posterior fontanelle of the cranium contains four apertures, two on each side of the median longitudinal line. The anterior and smaller member of each pair serves to transmit the ductus endolymphaticus, whilst the larger posterior aperture leads into the perilymph cavity surrounding the posterior vertical canal. The posterior aperture apparently corresponds to the tympanic aperture described by Howes (11) in Raia, and also mentioned by Goodey (6) as occurring in Chlamydoselachus anguineus.

Unfortunately the superficial portion of the ductus endolymphaticus was destroyed during the preparation of the skull, and we are therefore unable to give any account of its course outside the cranium. Judging, however, from the shallowness of the posterior fontanelle, and the fact that the skin was closely attached to the cranium in this region, it most probably runs straight to the dorsal surface of the head.

The membranous labyrinth (text-figs. 5 \& 6 ) of the right side of the head has been dissected out, by removing the surrounding cartilage, and serves as the basis of the following description.

In this account we have adopted the nomenclature used by Stewart (15) in preference to that used by Retzius (14).

The ducius endolymphaticus (d.e.) runs downwards and bifurcates at its lower end; a main branch going to the sacculus $(s$.) and a smaller branch opening into the recessus utriculi $(r . u$.$) .$ Our observations on this point do not agree with those of Ayers (1), who states:- "I have not seen the bifurcate endolymphatic duct, described by Hasse for the species which he studied, but the two endolymphatic tubes observed by $\mathbf{E}$. $\mathbf{H}$. Weber I have found beautifully developed in Sphyrna zygcena, and there is not the slightest doubt as to their occurrence."

We have been unable to trace Hasse's statement in his paper (8) or to ascertain what species he studied. There is, however, no doubt whatever that the endolymphatic duct does bifurcate at its lower end. The second duct present is not an endolymphatic 
duct but leads into the posterior perilymph cavity. This observation agrees with that of Goodey (6) on the posterior duct in Chlamydoselachus anguineus.

The Utriculus, as in nearly all Elasmobranchs, is divided into two portions, anterior and posterior, which do not communicate directly with one another, but indirectly through the sacculus.

The anterior utricle (u.a.) is circular in transverse section and gives off the anterior canal (c.a.) at its dorsal end. The canal runs forward and slightly outward, and expands at its lower end into the anterior ampulla (a.a.). The anterior utricle and the anterior canal together form an oval.

The anterior utricle also gives off posteriorly, at about the middle of its length, the external canal (c.e.), which runs at first downward and outward, and secondly horizontally. At its anterior end it expands into the external ampulla (a.e.), which communicates again with the anterior utricle through a short canal running dorsal to the recessus utriculi, but having no direct connection with it.

On the ventral side of the anterior utricle is a sac, the recessus utriculi $(r . u$.$) , which is somewhat flattened from side to side, and$ almost triangular in lateral view. It communicates with the anterior utricle through a smail aperture, whilst another small aperture, situated near the opening into the utricle, opens into the sacculus.

The posterior utricle (u.p.) is the portion of the labyrinth situated nearest to the median longitudinal line of the cranium. It has direct communication with the sacculus through a short duct, the ductus utriculo saccularis posterior (d.u.s.p.). The dorsal end of the posterior utricle gives off the posterior canal (c.p.), which runs downward and outward and after expanding into the posterior ampulla (a.p.) opens into the ventral end of the utricle.

The sacculus (s.) and lagena (l.) are laterally compressed; the latter being given off as a simple pouch at the infero-posterior end of the sacculus. The outer face of the sacculus and lagena is directed outward at an angle to the median plane.

\section{Nerve Supply.}

The membranous labyrinth is supplied by branches of the eighth cranial nerve.

The main nerve gives off a branch which runs beneath the recessus utriculi and then bends upward. It then bifurcates to form the ramulus ampulla anterior (r.a.a.) and the ramulus ampulla externus (r.a.e.). A longer and finer branch, the ramulus ampulla posterior (r.a.p.), comes off from the main nerve and runs on the inner side of the sacculus to the posterior ampulla, giving off tiny ramuli to the sacculus and lagena en route. We were unable to trace the ramulus utriculi in our specimen, and it is probably very small.

The membranous labyrinth resembles in many respects that of Cestracion philippi. 
Text-figures $5 \& 6$.

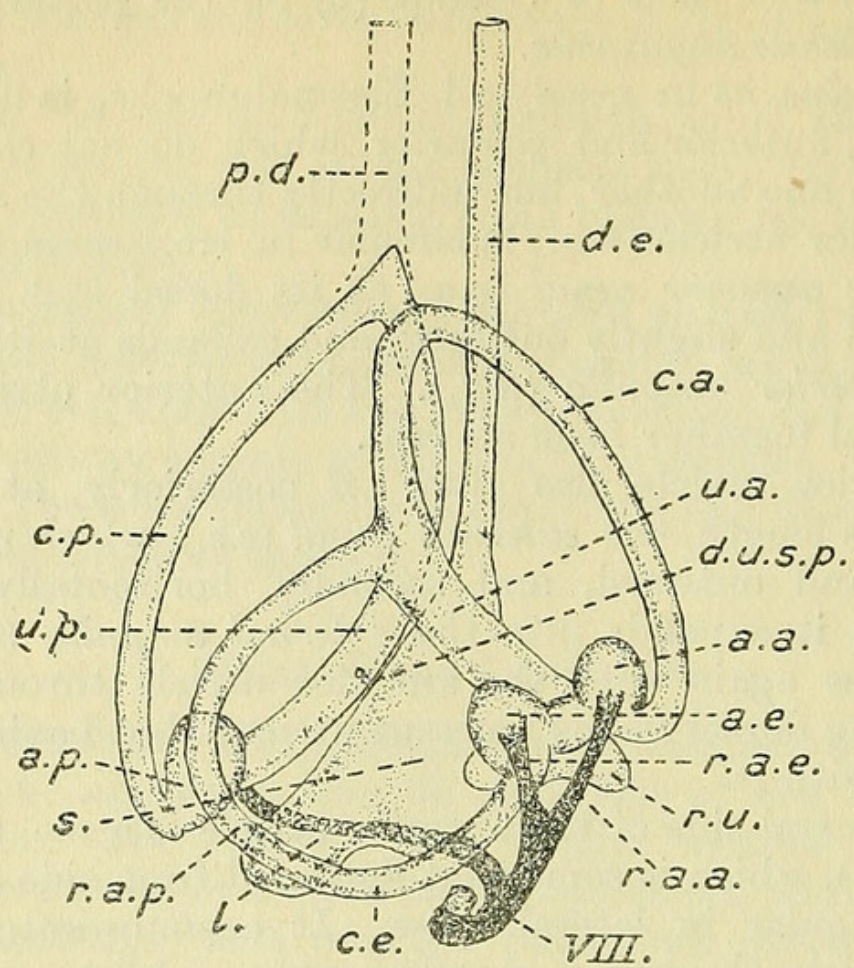

Right Membranous Labyrinth. (Outer view.)

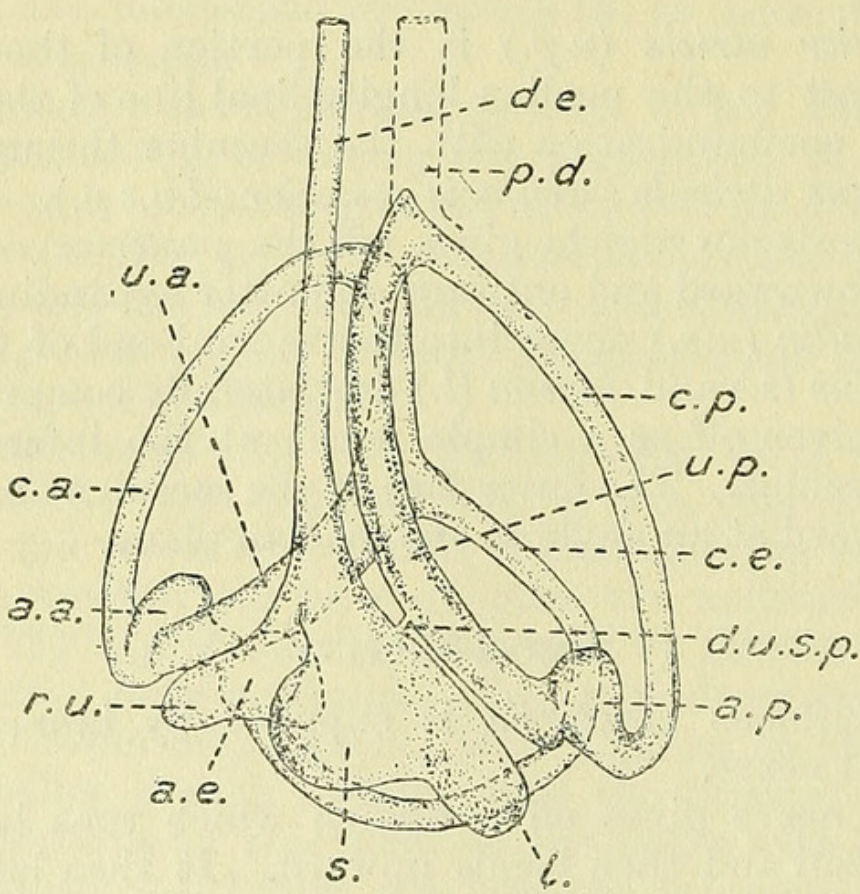

Right Membranous Labyrinth. (Inner view.)

a.a. ampulla anterior.

a.e. ampulla externus.

a.p. ampulla posterior.

c.a. canalis anterior.

c.e. canalis externus.

c.p. canalis posterior.

d.e. ductus endolymphaticus.

d.u.s.p. ductus utriculo saccularis posterior. l. lagena.

$p . d$. perilymph duct.

r.a.a. ramulus ampulla anterior.

r.a.e. ramulus ampulla externus.

r.a.p. ramulus ampulla posterior.

$r . u$. recessus utriculi.

u.a. utriculus anterior.

u.p. utriculus posterior.

VIII. 8th cranial nerve. 
Brain and Crantal Nerves.

Busch (2) and Miklucho-Maclay (12) have briefly, and on the whole accurately, described and figured the macroscopic structure of the brain. Owing to the poor condition of our specimen we are not able to add much to their account, but there are a few points on which our observations do not agree with theirs.

The brain is antero-posteriorly shortened and, in dorsal view, only a portion of the olfactory lobes (o.l.), the prosencephalon (f.b.), the much convoluted cerebellum (c.), the restiform bodies (r.b.), and the short medulla oblongata $(m$.) are visible (text-fig. 7 ). The diencephalon and optic lobes are completely covered by the cerebellum.

The prosencephalon is single and shows no trace of a median fissure.

The large paired olfactory lobes are situated ventral to the prosencephalon; only their anterior ends being visible in dorsal view.

Owing to the intimate relation of the olfactory lobes and the prosencephalon Busch (2) has named them the "lobes communes," and a section through the forebrain appears to justify this name. On the other hand, in his diagram he shows the prosencephalon as a paired structure and the olfactory lobes as unpaired. This is opposed to our observations.

The cerebellum is roughly triangular in shape, the base of the triangle being closely apposed to the posterior of the prosencephalon, and its apex posterior. It is primarily divided into three segments ; two of these being anterior, right and left, and the third running obliquely backward from the right. The left anterior segment is approximately equal in size to the posterior segment, but the right anterior segment is considerably smaller. All three segments are further divided into smaller segments, which in turn are sulcated.

Ventral to the posterior end of the cerebellum are two small oval lobes called by Miklucho-Maclay (12) the lobi trigemini $(l t$.$) .$

The restiform bodies (r.b.) are well developed and occupy their normal position. The medulla oblongata $(m$. $)$ is very short, and the fourth ventricle is correspondingly reduced.

In ventral view the olfactory lobes completely cover the prosencephalon. The optic chiasma lies immediately posterior to the olfactory lobes.

The infundibulum is well developed, and the saccus vasculosus shows on each side. Portions of the optic lobes are also visible in this view.

An examination of a median longitudinal section confirms Miklucho-Maclay's observation that a wedge-shaped portion of the cerebellum projects into the ventricle of the "Zwischenhirn."

The following Notes on the cranial nerves were made chiefly during the preparation of the skull, and are consequently far from complete.

The olfactory nerve is large and is given off laterally from the 
olfactory lobe. It runs attached to the posterior border of the laterally elongated olfactory sac, which is placed in the laterally expanded olfactory capsule. The portion of the nerve adherent to the sac is called the olfactory bulb by Busch (2), whose figure shows it expanded rather more than is the case in our specimen. To verify Busch's statement we have sectioned a portion of the nerve taken from the region of the sac, but we have failed to find any trace of nerve cells. This, however, may be accounted for by the fact that our material was not in the best state of preservation.

\section{Text-figure 7.}

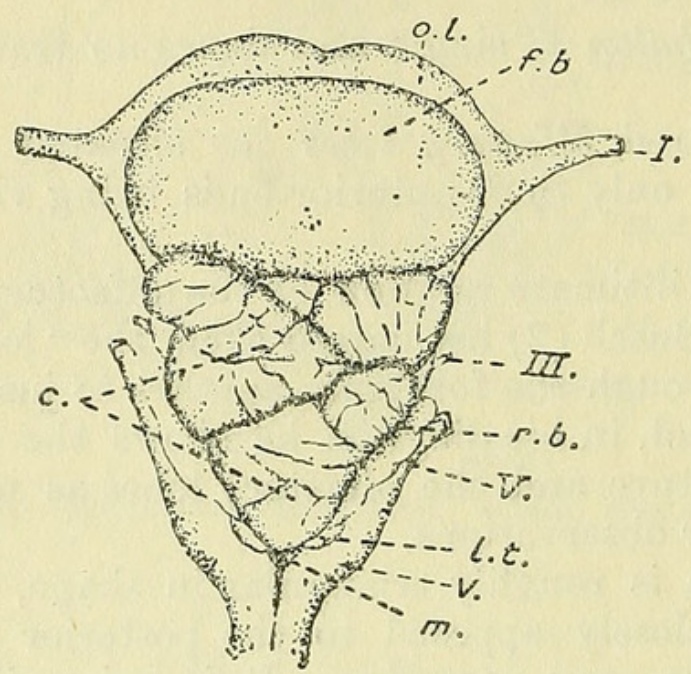

Dorsal View of Brain.

c. cerebellum.

f.b. prosencephalon.

l.t. lobi trigemini.

m. medulla oblongata. o.l. olfactory lobes.

$r . b$. restiform bodies.

$v$. 4th ventricle.

I, III, V. cranial nerves.

The optic nerve runs on the ventral side of the hammer just anterior to the auditory process.

The oculomotor nerve runs for the greater portion of its length posterior to the optic, but crosses it ventrally about an inch from the orbit and is distributed to the inferior oblique, anterior rectus, and inferior rectus muscles. A distinct branch of the nerve runs parallel to the main branch and supplies the superior rectus muscle.

The pathetic nerve runs antero-dorsal to the optic and supplies the superior oblique muscle.

The ophthalmic branches of the fifth and seventh nerves run directly to the anterior end of the dorsal surface of the snout. The fifth, in addition, sends off a lateral branch to a patch of ampullary canals just mesial of the orbit.

The mandibular and maxillary branches of the trigeminal have the normal distribution.

The abducens runs ventral to the auditory process and supplies the posterior rectus muscle. 
The hyomandibular branch of the seventh nerve runs posterior to the mandibular branch of the fifth and gives off an external mandibular.

The auditory nerve has already been described in relation to the membranous labyrinth.

\section{Summary.}

The following are the important points dealt with in the paper :-

1. The skull, except the jaws, has been described in detail.

2. The membranous labyrinth has been described and figured for the first time.

3. The existing accounts of the macroscopic structure of the brain have been revised, and notes have been included on the relationships of most of the cranial nerves.

\section{Literature.}

1. Arers.-_" Contribution to the Morphology of the Vertebrate Ear." J. Morph. vi. 1892.

2. Busch.-De Selachiorum et Ganoideorum Encephalo. Berolini, 1848.

3. DAY.-The Fishes of India. 1878.

4. Garman._"The Plagiostoma." Cambridge, Mass., Mem. Mus. Comp. Zool. Harvard Coll. 36, 1913.

5. Gegenbaur.--Unters. z. vergl. Anat. d, Wirbelthiere, iii. 1872.

6. Goodey.-" A Contribution to the Skeletal Anatomy of the Frilled Shark, Chlamydoselachus anguineus Gar." Proc. Zool. Soc. 1910.

1\%. Goodrich.-A Treatise on Zoology. Pt. 9, 1st Fasc. Cyclostomes and Fishes. London, 1909.

8. Hasse.- "Bemerkungen über das Gehörorgan der Fische." Verhandl. der Phys. Med. Gesell. in Würzb., N. F. i. 1868.

9. Haswell._- "Studies on the Elasmobranch Skeleton." Proc. Linn. Soc. N. S. Wales, vol. ix., 1884.

10. Hemprich \& Ehrenberg.-Symbolæ Physicæ. Zoologica. Berlin, 1899.

11. Howes.- "On the presence of a Tympanum in the Genus Raia." Journ. Anat. \& Physiol. vol. xvii., 1883.

12. Miklucho-Maclay.-Beiträge z. vergl. Neur. d. Wirbelthiere. I. Das Gehirn. d. Selachier. Leipzig, 1870.

13. Parker. " "Notes on Carcharodon rondeletii." Proc. Zool. Soc. 1887.

14. Retzius.-Das Gehörogan d. Wirbelthiere. Bd. I. Stockholm, 1881.

15. Stewart. "On the Membranous Labyrinth of Certain Sharks.” Journ. Linn. Soc., Zool. vol. xxix., 1906.

Proc. Zool. Soc.-1922, No. LXVI. 


\section{$2 \mathrm{BHL}$ Biodiversity Heritage Library}

Lloyd, J H and Sheppard, Edith M. 1922. "A Contribution to the Anatomy of a Hammerhead Shark (Zygœna malleus Shaw)." Proceedings of the Zoological Society of London 1922, 971-981.

https://doi.org/10.1111/j.1469-7998.1922.tb07092.x.

View This Item Online: https://www.biodiversitylibrary.org/item/100613

DOI: https://doi.org/10.1111/j.1469-7998.1922.tb07092.x

Permalink: https://www.biodiversitylibrary.org/partpdf/72064

\section{Holding Institution}

Smithsonian Libraries

\section{Sponsored by}

Biodiversity Heritage Library

\section{Copyright \& Reuse}

Copyright Status: Public domain. The BHL considers that this work is no longer under copyright protection.

This document was created from content at the Biodiversity Heritage Library, the world's largest open access digital library for biodiversity literature and archives. Visit BHL at https://www.biodiversitylibrary.org. 